\title{
Patterns of genetic diversity and structure in Antarctic and sub-Antarctic Nacella (Patellogastropoda: Nacellidae) species
}

\author{
Claudio A. González-Wevar, ${ }^{a, b}$, Mathias Hüne ${ }^{b, c}$, Sebastián Rosenfeld ${ }^{a, b}$, Thomas Saucède ${ }^{d}$, Jean-Pierre Férale, \\ Andrés Mansillab,f and Elie Poulin ${ }^{b}$
}

${ }^{a}$ GAIA Antártica/Departamento de Recursos Naturales, Universidad de Magallanes, Bulnes 01890, Punta Arenas, Chile; ${ }^{b}$ Instituto de Ecología y Biodiversidad (IEB), Departamento de Ciencias Ecológicas, Facultad de Ciencias, Universidad de Chile, Las Palmeras \#3425, Ñuñoa, Santiago, Chile;

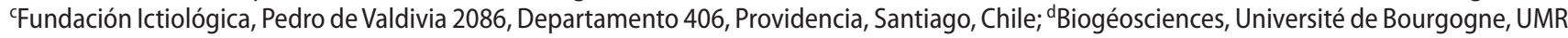
CNRS 6282, Dijon, France; 'Institut Méditerrané de Biodiversité et d'Ecologie marine et continentale, Aix Marseille Université-CNR-IRD-Avignon Université, Marseille, France; 'Departamento de Recursos Naturales, Universidad de Magallanes, Avenida Bulnes 01890, XII Región de Magallanes y de la Antártica Chilena, Punta Arenas, Chile

\begin{abstract}
The biogeography of the Southern Ocean reflects complex interactions between major macro-evolutionary forces and biotic elements. Major gateway openings, the establishment of the Antarctic Circumpolar Current and climate cooling are deeply connected to the composition, abundance and distribution of the Southern Ocean marine benthic fauna. Glacial episodes of the Quaternary heavily impacted the distribution of the genetic variation of the Southern Ocean biota. The genus Nacella includes 12 nominal species in different provinces of the Southern Ocean. In this study, we compared patterns of mitochondrial DNA diversity in three Nacella species from Antarctic Peninsula, Kerguelen Island and Patagonia. Low levels of genetic diversity and absence of genetic structure characterise each one of them showing the strong impact of ice advances and retreats over their respective demographics. Haplotype diversity, short genealogies and demographic inference recorded suggest the occurrence of a more dramatic demographic process in Antarctic Peninsula than in the sub-Antarctic.
\end{abstract}

KEYWORDS

Southern Ocean; biogeography; phylogeography; Antarctic Circumpolar Current; Last Glacial Maximum; Nacella

\section{Introduction}

The Southern Ocean encircling the Antarctic continent covers an area of approximately 35 million $\mathrm{km}^{2}$, represents $8 \%$ of the world's ocean surface and is considered as a major driver of global oceanic circulation (Rintoul, Hughes, and Olbers 2001). This vast region harbours approximately a $5 \%$ of the marine diversity (Barnes, Griffiths, and Kaiser 2009; Barnes and Peck 2008). The distribution of the marine benthic biota in Antarctic and sub-Antarctic provinces largely reflects the interaction of tectonics, climate, oceanography and biotic elements at different temporal and spatial scales (Aronson et al. 2007; Crame 1999; Griffiths, Barnes, and Linse 2009; Pierrat et al. 2013). According to Mackensen (2004) three main periods dramatically affected the biogeography of the Southern Ocean. First, the Eocene/Oligocene boundary ( 34 Ma) marks the onset of the Antarctic isolation by the formation of major gateway openings and the initiation of the
Antarctic Circumpolar Current (ACC; Barker and Thomas 2004; Barker et al. 2007; Pfuhl and McCave 2005; Scher et al. 2015; Zachos et al. 2001). This current represents the major oceanographic system of the planet delimited by two boundaries, the Antarctic Polar Front (APF) and the sub-Antarctic Front (SAF; Barker et al. 2007; Rintoul, Hughes, and Olbers 2001). The positions of these fronts have major biogeographical implications for the Southern Ocean biota (González-Wevar et al. 2010; 2012a; Griffiths, Barnes, and Linse 2009; Pierrat et al. 2013; Poulin et al. 2014; Strugnell et al. 2008). The ACC acts as an effective barrier for many invertebrate taxa, especially between Antarctic and sub-Antarctic provinces (Barnes et al. 2006; Clarke, Barnes, and Hodgson 2005; González-Wevar et al. 2012a; : Poulin et al. 2014; Shaw, Arkhipkin, and Al-Khairulla 2004). In contrast, across the sub-Antarctic the ACC acts as an important carrier of organisms between geographically distant provinces, especially for those species 
with high dispersive potential (Díaz et al. 2011; Fraser et al. 2009; Waters 2008) and to kelp-dwelling organisms (Cumming et al. 2014; Fraser, Nikula, and Waters 2011; Nikula et al. 2010). Second, the middle Miocene ( 14 Ma) associated to an increased southern bottom formation, the intensification of the ACC and the re-establishment of a permanent ice sheet on East Antarctic and along the Pacific margin of West Antarctica (Lawver and Gahagan 2003; Verducci et al. 2009). Recent molecular studies between Antarctic and sub-Antarctic congeneric species in different marine invertebrates groups (González-Wevar et al. 2012a; Poulin et al. 2014) indicate that their respective separations occurred long after the physical separation of both continents. Molecular divergence between Antarctic and South American lineages seems to be related to important changes in the Southern Ocean including the evolution of the Scotia Arc and a late deepening of the Drake Passage until the middle Miocene (Dalziel et al. 2013). Together with these tectonic and oceanographic changes, climate shift has exerted a major role in the Southern Ocean, shaping the abundance, structure and distribution of its biota (Aronson et al. 2007; Clarke and Crame 1989, 2010). Finally, the Quaternary is characterised by the alternation between glacial and interglacial episodes that greatly affected seasonality and intensity of sea-ice formation, as well as the position of the ACC (Gersonde et al. 2005; Kemp et al. 2010). Furthermore, the development of large ice sheets during glacial periods exerted major changes in the spatial distribution and demography of populations, species and communities, especially at higher latitudes (Hewitt 2000; Provan and Bennett 2008). For instance, ice advances and retreats radically altered the geographical range of the species and populations sizes and therefore deeply affected the distribution of intraspecific genetic variation (Allcock and Strugnell 2012; Maggs et al. 2008; Provan and Bennett 2008). Near-shore marine benthic communities in the Southern Ocean, and particularly those from Antarctica, would have been especially vulnerable to grounded ice sheets (Dambach et al. 2012; Thatje, Hillenbrand, and Larter 2005). Therefore, it is expected a direct relationship between latitude and the impact of continental- and sea-ice formation over the demography of populations and species.

True limpets of the genus Nacella includes at least 11 nominal species distributed in Antarctic and sub-Antarctic provinces where they are dominant shallow macrobenthic invertebrates of inter- and sub-tidal rocky ecosystems (González-Wevar et al. 2011; Powell 1973; Valdovinos and Rüth 2005). Almost half of the species of Nacella are endemic to particular isolated oceanic subAntarctic islands. For instance, N. delesserti, N. edgari and $N$. terroris are found at Marion, Kerguelen and Campbell islands, respectively. The Antarctic limpet, N. concinna, is currently distributed in ice-free rocky areas along maritime Antarctica and some peri-Antarctic islands inside the APF (South Georgia, South Sandwich and Bouvet). South America harbours the greatest diversity for the genus with nine nominal species described, eight of them found along the Patagonian coast (Powell 1973; Valdovinos and Rüth 2005). Nevertheless, recent phylogenetic reconstructions and divergence time estimations based on mitochondrial DNA (mtDNA) markers indicate that this Patagonian radiation of the genus represents the most derived one (González-Wevar et al. 2010) and only four of the nominal species (N. magellanica, N. deaurata, N. mytilina and $N$. flammea) constitute significant evolutionary units (SEUs; González-Wevar et al. 2011). Among them, N. magellanica exhibits the broadest distribution from Chiloé Island in the Pacific to Río Negro Province in the Atlantic including the Patagonian fjords, the Strait of Magellan, Tierra del Fuego, Cape Horn and the Falkland/Malvinas Islands (Powell 1973; Valdovinos and Rüth 2005).

One of the main purposes of this study was to evaluate the levels of molecular divergence among congeneric broadcaster-spawners Nacella species from Kerguelen Island (N. edgari), maritime Antarctica (N. concinna) and Patagonia (N. magellanica). The information contained in their DNA sequences will permit us to determine the rhythms and trends in the biogeography of this important marine benthic group. Secondly, we estimated patterns of genetic diversity and structure in each one of the analysed species/provinces in order to further understand the impact of the Quaternary glacial processes along a latitudinal gradient.

\section{Methods}

Nacella species were identified following Powell (1973) and Valdovinos and Rüth (2005). Intertidal and subtidal individuals of N. edgari were sampled at different localities of Kerguelen (Table 1) and were included alongside previously published data on N. magellanica (GonzálezWevar et al. 2012b) and N. concinna (González-Wevar et al. 2013). For comparison purposes, we included in the analyses a similar number of individuals per locality/ area. All the specimens were fixed in ethanol (95\%) and DNA was extracted from the mantle and the pedal muscle using a salting-out method (Aljanabi and Martinez 1997). We amplified a partial fragment of the mitochondrial cytochrome c oxidase subunit I (COI) gene using universal (Folmer et al. 1994) and specific (González-Wevar et al. 2010) primers. Polymerase chain reaction (PCR) procedures were prepared in a $25 \mu \mathrm{l}$ reaction containing $2.5 \mu \mathrm{l}$ 10X Buffer ( $50 \mathrm{mM} \mathrm{KCl,} 10 \mathrm{mM}$ Tris- $\mathrm{HCl}, \mathrm{pH} 8.0$ ), $1.0 \mu \mathrm{l}$ of $50 \mathrm{mM} \mathrm{MgCl}, 200 \mathrm{mM}$ dNTPs, $0.5 \mu \mathrm{l}$ of each primer $(10 \mathrm{pg} / \mu \mathrm{l}), 1 \mathrm{U}$ Taq (Invitrogen), $17.5 \mu \mathrm{l}$ of double-distilled water and $50 \mathrm{ng}$ of DNA. Thermal cycling parameters 
Table 1. Diversity indices and neutrality tests in Nacella species from different provinces of the Southern Ocean, including N. edgari (Kerguelen Island), N. concinna (maritime Antarctica) and N. magellanica (Patagonia).

\begin{tabular}{|c|c|c|c|c|c|c|c|c|}
\hline Species and localities & $n$ & $k$ & $H$ & $S$ & $\Pi$ & $\pi$ & Tajima's D & Fu's FS \\
\hline \multicolumn{9}{|l|}{ N. edgari } \\
\hline Port Christmas & 28 & 7 & 0.767 & 8 & 1.354 & 0.0019 & & \\
\hline Port Aux Francais & 32 & 9 & 0.633 & 8 & 0.869 & 0.0012 & & \\
\hline Ile du Prince de Monaco & 41 & 13 & 0.788 & 15 & 1.505 & 0.0021 & & \\
\hline Total & 101 & 20 & 0.750 & 19 & 1.287 & 0.0018 & $-1.92^{*}$ & $-16.013^{* * * *}$ \\
\hline \multicolumn{9}{|l|}{ N. concinna } \\
\hline Antarctic Peninsula & 31 & 5 & 0.688 & 5 & 0.985 & 0.0014 & & \\
\hline South Shetland Island & 32 & 6 & 0.573 & 6 & 0.724 & 0.0010 & & \\
\hline South Orkney Island & 26 & 9 & 0.625 & 8 & 0.757 & 0.0011 & & \\
\hline Total & 89 & 12 & 0.0627 & 11 & 0.827 & 0.0012 & $-1.84^{*}$ & $-8.07^{* * *}$ \\
\hline \multicolumn{9}{|l|}{ N. magellanica } \\
\hline Metri & 25 & 9 & 0.743 & 10 & 1.380 & 0.0020 & & \\
\hline Aysén & 24 & 6 & 0.496 & 6 & 0.790 & 0.0011 & & \\
\hline Santa Ana & 24 & 10 & 0.775 & 11 & 1.365 & 0.0020 & & \\
\hline Tekenika & 24 & 11 & 0.822 & 13 & 1.822 & 0.0027 & & \\
\hline Total & 97 & 25 & 0.714 & 28 & 1.409 & 0.0022 & $-2.24^{* *}$ & $-24.33^{* * *}$ \\
\hline
\end{tabular}

Notes: $n=$ number of analysed individuals; $k=$ number of haplotypes; $S=$ polymorphic sites; $H=$ haplotype diversity; $\Pi=$ average number of pairwise differences; $\pi=$ nucleotide diversity.

${ }^{*} p<0.05$.

${ }^{* *} p<0.01$.

${ }^{* * *} p<0.001$.

included an initial denaturation step at $94{ }^{\circ} \mathrm{C}$ for $5 \mathrm{~min}$, followed by 35 cycles at $94{ }^{\circ} \mathrm{C}$ for $1 \mathrm{~min}, 48^{\circ} \mathrm{C}$ for $1 \mathrm{~min}$ and $72{ }^{\circ} \mathrm{C}$ for $1 \mathrm{~min}$, and a final extension at $72{ }^{\circ} \mathrm{C}$ for $5 \mathrm{~min}$. PCR amplification products were purified using QIAquick Gel Extraction Kit (QIAGEN) and sequenced in both directions at Macrogen Inc (Seoul, Korea). Forward and reverse sequences of each gene were assembled independently and edited using Proseq v.3.5 (Filatov 2009) and aligned with Muscle (Edgar 2004). Sequences were translated to amino acids to check for the presence of pseudogenes and/or sequencing errors in MEGA v6.0 (Tamura et al. 2013). Similarly, MEGA was used to determine base composition and we performed a DNA saturation analysis following Roe and Sperling (2007) to evaluate how saturation of transitions are accumulated in relation to nucleotide divergence in the complete COI data-set.

We estimated the average number of nucleotide substitutions and calculated the pairwise percent of divergence (uncorrected p-distances) among Nacella lineages from different provinces of the Southern Ocean. We determined whether the evolutionary rate was constant in the analysed taxa using a likelihood ratio test (Felsenstein 1981) in DAMBE (Xia and Xie 2001). Once the constancy of the evolutionary rate was confirmed we performed divergence time estimations among the analysed lineages using a strict molecular clock hypothesis (MCH) and specific evolutionary rates (González-Wevar et al. 2010). This hypothesis assumes that DNA and protein sequences evolve at a constant rate through time and therefore the genetic divergence between any two species is proportional to the time since they last shared a common ancestor (Bromham and Penny 2003). We constructed maximum parsimony genealogical relationships among Nacella lineages using
Hapview. This methodology allows a simple reconstruction of phylogenies based on intraspecific genetic data (Posada and Crandall 2001).

Levels of polymorphism were calculated using standard mtDNA genetic diversity indices including the number of haplotypes $(k)$, the number of segregating sites $(S)$, haplotype diversity $(H)$, the average number of pairwise differences $(\Pi)$ and nucleotide diversity $(\pi)$ at each locality and for each of the analysed species using DnaSP v.5.00.07 (Librado and Rozas 2009). We performed neutrality statistical tests (Tajima's D and Fu's $\mathrm{F}_{\mathrm{S}}$ ) to estimate if COI sequences in deviate from expectations under a neutral model. We determined the level of genetic differentiation among localities for each of the analysed species based on haplotype frequencies $\left(G_{\mathrm{ST}}\right)$ and mean pairwise differences $\left(N_{\mathrm{ST}}\right)$ following Pons and Petit (1996) in Arlequin (Excoffier, Laval, and Schneider 2005). We test the statistical significance of the genetic differentiation using permutation tests (20,000 iterations) of haplotype identities. We inferred the spatial genetic structure for each species by estimating the number and composition of groups that were most differentiated based on sequence data-set with an analysis of molecular variance (AMOVA) in Arlequin. AMOVA allows using multiple spatial scales in statistical methods to characterise the spatial genetic structure by partitioning it into: within populations, among populations within groups and among groups.

We constructed genealogical relationships in the different species of Nacella using maximum parsimony networks in Hapview (http://www.cibiv.at). Finally, we compared the patterns of demographic history in the analysed Nacella species using the distribution of pairwise differences between haplotypes (mismatch distribution) 
and by comparing it to the expected distribution under the sudden expansion growth model (Rogers and Harpending 1992). This is a common method in demographic inference analyses considering that the amount of nucleotide differences between haplotypes depends on the length of time since they diverged.

\section{Results}

COI sequences in the analysed Nacella species were $658 \mathrm{bp}$ long and, as expected working with coding sequences, no indels or stop codons were detected when comparing the alignment to the translated open reading frame. Sequences were not saturated at any position but we recognised a high degree of genetic polymorphism among the analysed Nacella species. 100 positions were variable (15.19\%) of which 85 (85\%) were parsimoniously informative. We recognise two amino acid changes (positions 106 and 157), one transition (from A to G in site 157) and one transversion (from $T$ to $G$ in site 106). As previously estimated in Nacella species, sequences were A-T rich (60.4\%) compared with the mean G-C content.

As previously estimated in the genus, main patterns of genetic divergence among Nacella lineages from maritime Antarctica, Patagonia and sub-Antarctic Kerguelen Island indicate a marked distinction among them (Figure 2(a)). By analysing these results under a phylogenetic framework (González-Wevar et al. 2016), an early separation of Nacella into two main clades is detected. The first one includes lineages from South America and the second one those species from maritime Antarctica and from subAntarctic islands. The molecular divergences between Antarctic N. concinna and its sub-Antarctic relatives $N$. edgari and N. magellanica were $6.9 \%$ and $8.3 \%$, respectively. The divergence between sub-Antarctic South American $N$. magellanica and sub-Antarctic Kerguelen Island $N$. edgari was $8.0 \%$. Considering a specific substitution rate for nacellids (González-Wevar et al. 2011), the divergence among the analysed lineages of Nacella ranged between 3.5 Ma and 4.2 Ma. The last contact between $N$. concinna from maritime Antarctica and N. edgari from Kerguelen Island occurred 3.5 Ma. The last contact between N. concinna from maritime Antarctica and N. magellanica from Patagonia occurred 4.15 Ma. Finally, the last contact between N. magellanica from Patagonia and N. edgari from Kerguelen Island occurred 4.0 Ma.

After this Pliocene diversification, each one of the analysed species/lineages of Nacella followed different evolutionary pathways in distinct provinces of the Southern Ocean (South America, maritime Antarctica and Kerguelen Island). Nevertheless, short-term phylogeographic analyses recognised similar demographic signals in the analysed species of Nacella. In general terms, all the analysed species of Nacella showed low levels of genetic diversity and absence of structure along their respective distributions in Antarctic and sub-Antarctic areas. Patterns of genetic diversity among the analysed species of Nacella showed higher levels of polymorphism in species from the sub-Antarctic (South America and Kerguelen Island) than in the Antarctic limpet N. concinna (Table 1). In fact, all the analysed indices detected higher levels of diversity in N. edgari (Kerguelen Island) and N. magellanica (Patagonia), compared to $N$. concinna from maritime Antarctica. Pairwise $N_{\mathrm{ST}}$ and $G_{\mathrm{ST}}$ comparisons within each of the analysed Nacella species detected an absence of genetic structure in each of the analysed species.

Haplotype networks (Figure 1(a) and 1(b)) showed similar patterns in the different species of Nacella with typical star-like topologies and short genealogies. However, as previously estimated through standard diversity indices, the number of haplotypes was considerably lower in the Antarctic limpet $N$. concinna than in their sub-Antarctic relatives from Patagonia ( $N$. magellanica) and Kerguelen Island ( $N$. edgari). The maximum parsimony haplotype network in N. concinna included 12 haplotypes with a central haplotype (H1; Figure 2(b)) distributed at all localities an present in more than $58.42 \%$ of the individuals. A second haplotype was also broadly distributed along $N$. concinna distribution and present in $16.85 \%$ of the individuals. All the haplotypes in the Antarctic limpet are related to the dominant one through a branch length of one or two mutational steps (Figure 2(b)). The maximum parsimony haplotype network in sub-Antarctic Patagonian N. magellanica included a total of 25 different haplotypes. The dominant haplotype ( $\mathrm{H} 1$; Figure 2(c)) was present in $51.54 \%$ of the individuals and was recorded along the species distribution in the Pacific coast of Patagonia. A second haplotype (H2; Figure 2(c)) of medium frequency (14.43\%) was also found in all N. magellanica populations. All the haplotypes in N. magellanica are related to the dominant one (H1; Figure 2(c)) through a branch length of no more than three mutational steps. Finally, the maximum parsimony haplotype network in sub-Antarctic N. edgari from Kerguelen Island included a total of 21 different haplotypes. In this species, a dominant haplotype (H1; Figure $2(\mathrm{~d})$ ) was present in $45.54 \%$ of the individuals and was found in all the analysed populations. Two haplotypes $(\mathrm{H} 2$ and $\mathrm{H} 3$; Figure 2(d)) of medium frequencies (15.84\% and $13.86 \%$, respectively) were recorded in all the analysed N. edgari populations. All the haplotypes in N. edgari are related to the dominant one $(\mathrm{H} 1)$ through a branch length of no more than six mutational steps (Figure 2(d)). As expected for star-like topologies, general Tajima's and Fu's neutrality tests were both negative and significant for the whole COI data-set of each of the analysed 


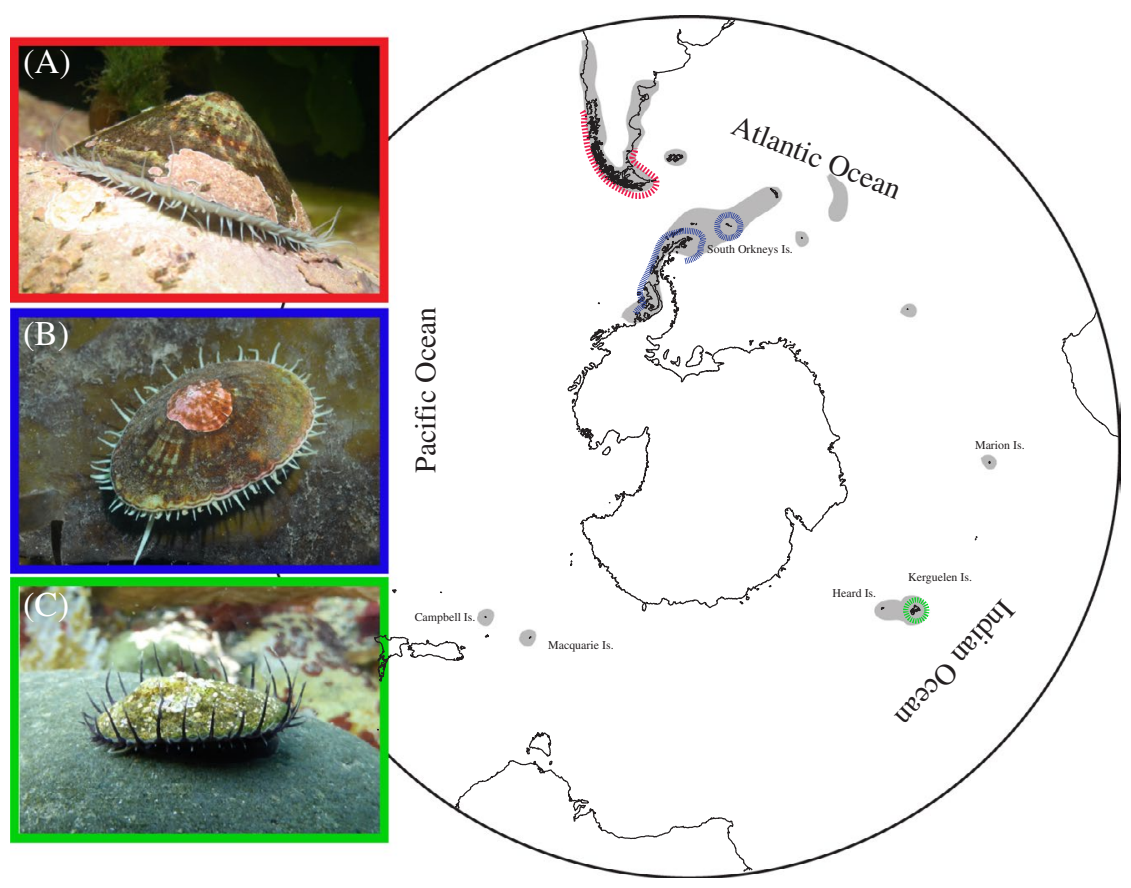

Figure 1. Distribution of Nacella in the Southern Ocean (in grey) including maritime Antarctica, South America and sub-Antarctic oceanic islands (Marion, Kerguelen, Heard, Macquarie and Campbell). Dashed coloured lines indicate the approximate distribution of the analysed Nacella species (red $=N$. magellanica, blue $=N$. concinna and green $=N$. edgari). Underwater photographs courtesy of César Cárdenas (N. magellanica), Dirk Schories (N. concinna) and Elie Poulin (N. edgari).

Nacella species (Table 1). Similarly, the distributions of pairwise differences between sequences in each of the analysed Nacella species were L-shaped for N. concinna and unimodal for N. edgari and N. magellanica due to the fact that the majority of the individuals shared the same haplotype. Considering a specific substitution rate for nacellids, demographic expansion would have started around 5500 years ago for N. concinna, around 7500 years ago for N. magellanica and around 4000 years ago for $N$. edgari, assuming the sudden growth model (Rogers and Harpending 1992).

\section{Discussion}

The emergence of new methodological approaches in molecular biology has renewed the interest on biogeographical studies, particularly in the Southern Ocean biota (Downey et al. 2012; Fraser et al. 2009; González-Wevar et al. 2010; 2012a; Griffiths, Barnes, and Linse 2009; Linse et al. 2006; Pierrat et al. 2013; Poulin et al. 2014). The use of diverse sources of data available from palaeogeographical, palaeoclimatic and palaeontological records and those obtained from DNA sequences make possible the interpretation of current distribution patterns in a more precise historical framework (Pearse et al. 2009).

Mitochondrial DNA comparisons in species of the genus Nacella from different provinces of the Southern Ocean recognised clear and marked genetic divergences between lineages from maritime
Antarctica, South America and Kerguelen Island. In this study, each one of the analysed species, maritime Antarctic N. concinna, South American N. magellanica and Kerguelen Island N. edgari, constitutes a different taxonomic units that have been separated for several millions of years. Divergence time estimations based on a specific substitution rate for nacellids indicate an effective separation among the analysed lineages of Nacella during the Pliocene between 3.5 and $4.2 \mathrm{Ma}$. Accordingly, the ACC constitutes an effective barrier for the analysed Nacella species between maritime Antarctic and the two sub-Antarctic lineages (southern South America and Kerguelen Island), respectively.

In contrast to the evidence of genetic identities recorded between geographically distant sub-Antarctic populations for mytiliids (Gérard et al. 2008), crustaceans (Nikula et al. 2010) echinoids (Díaz et al. 2011) and pulmonate gastropods (Cumming et al. 2014), geographical distance and oceanographical patterns in the region seem to represent an unbearable barrier for connectivity in Nacella, particularly between South America and sub-Antarctic islands like Marion (González-Wevar et al. in press) and Kerguelen Island (González-Wevar et al. 2010; this study). Similarly, a recent molecular study in the sea spider Austropallene cornigera also recognised clear evidence of genetic differentiation between Antarctic continental shelf and peri-Antarctic Bouvet Island populations suggesting a limited pattern of gene flow between these areas (Dömel, Convey, and Leese 2015). 


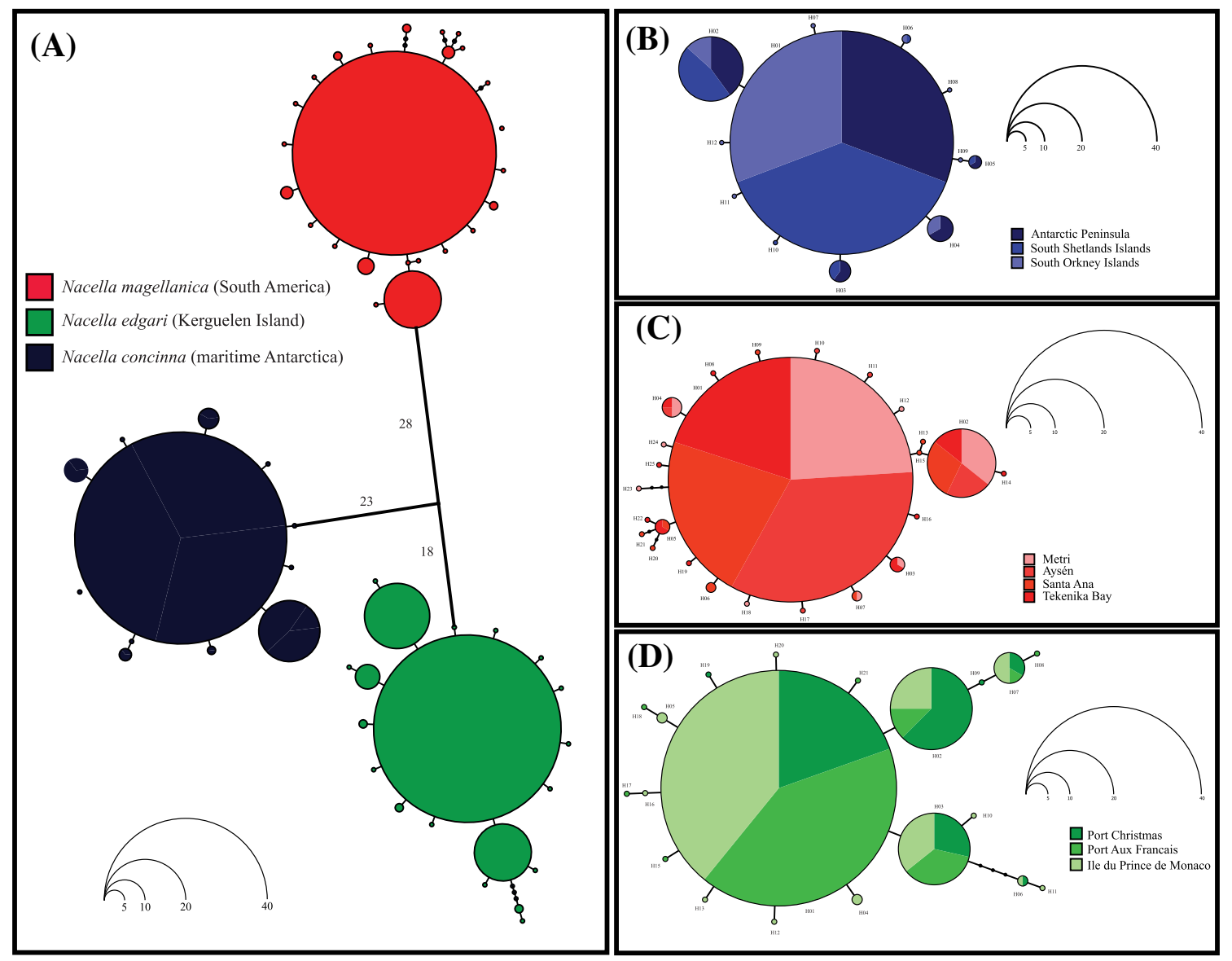

Figure 2. (a) General maximum parsimony haplotype networks in Nacella species showing the divergence (based on uncorrected p-distances) among them. A coloured circle indicating the province where it was collected represents each haplotype. Green = Kerguelen Island (N. edgari), blue = maritime Antarctica (N. concinna) and red = southern South America ( $N$. magellanica). The size of each circle is proportional to its frequency in the whole sampling effort. (b) Maximum parsimony haplotype network in N. concinna along maritime Antarctica. (c) Maximum parsimony haplotype network in N. magellanica from southern South America. (d) Maximum parsimony haplotype network in N. edgari along Kerguelen Island.

Under a phylogenetic framework (González-Wevar et al. 2010; in press), the origin and diversification of Nacella in different provinces of the Southern Ocean occurred during the mid- to late-Miocene, long after the physical separation of the continental landmasses estimated between $41 \mathrm{Ma}$ (Livermore et al. 2005) and 23.9 (Scher and Martin 2006) and to the initiation of the ACC. Such divergence within Nacella is basic agreement with recent molecular studies in notothenioid fishes (Near et al. 2012; Stankovic et al. 2002) and in different groups of marine invertebrates (Page and Linse 2002; Wilson, Schrödl, and Halanych 2009) showing recent processes of diversification in the Southern Ocean. In this context, levels of pairwise uncorrected p-distances recorded in Nacella are comparable to those detected between Antarctic and South American lineages of Astrotoma (Hunter and Halanych 2008), Odontaster (Janosik, Mahon, and Halanych 2011), Sterechinus (Poulin et al. 2014) and Yoldia (González-Wevar et al. 2012a; Poulin et al. 2014). Therefore, the onset of divergence in different
Southern Ocean invertebrate taxa does not appear to be a direct consequence of continental drift processes occurred in the region since the Mesozoic but to more recent oceanographic/climatic processes during the Miocene (Mackensen 2004; Verducci et al. 2009; Zachos et al. 2001).

In this context, Dalziel et al. (2013) have argued that the full development of a deep ACC was only achieved during the late Miocene ( $12 \mathrm{Ma})$ and not earlier, at the Eocene/Oligocene boundary, as long surmised. The formation of a full deep ACC may have played an important role in the subsequent Antarctic cryosphere expansion (Zachos et al. 2001), as well as in the intensification of the ACC associated with an increased strength of the westerly winds (Flower and Kennett 1994; Shevenell, Kennett, and Lea 2004). Such oceanographic/climatic processes would have promoted the separation between the different lineages of Nacella that are currently distributed in different provinces of the Southern Ocean.

Over the last two million years the climate on Earth has undergone recurring fluctuations that resulted in the Ice 
Ages of the Quaternary. A vast body of evidence clearly demonstrates that many species experienced major and rapid latitudinal shifts as a response to ice advances and retreats during the Pleistocene (Marko et al. 2010; Provan and Bennett 2008). Several studies have demonstrated the impact of Quaternary glacial processes over population dynamics and the demography of different Southern Ocean invertebrates (Convey et al. 2009; Fraser et al. 2009; 2010; Allcock and Strugnell 2012; González-Wevar et al. 2012a; in press). Fossil records and biogeographical data indicate that most of the biota, and particularly cold temperate species, persisted through glacial maxima in lower latitude refugia, where climatic conditions were less extreme (Hewitt 2000; Provan and Bennett 2008). Hence, ice advances during colder glacial periods generated major reduction of shallow rocky habitat and should have generated reduction in population sizes. Accordingly, a marked decline in genetic diversity through bottleneck effects or founder effects followed by population expansion is expected (Slatkin and Hudson 1991). Relatively little is known on how and where ice-sensitive benthic biota of Antarctic and sub-Antarctic regions would have endured processes of extinction and recolonization as sea ice covered the region (Fraser et al. 2009). Ice shelves during glacial maxima extended even further and summer sea ice extended north of the $60^{\circ} \mathrm{S}$ (Gersonde et al. 2005), and thus restricted light penetration and primary production. However, the benthic marine fauna in the Southern Ocean did survive and new molecular data are helping to further elucidate how and where (Allcock and Strugnell 2012).

As general pattern, Antarctic and sub-Antarctic Nacella species showed a strong signal of postglacial population expansion with the presence, in each of the analysed species, of a dominant haplotype surrounded by several unique or low-frequency haplotypes, commonly known as star-like genealogy. Such results are evidence of the impact of glacial processes over the demography of both Antarctic and sub-Antarctic near-shore benthic taxa, resulting in a reduction in their population size and probably their distribution, during the coolest periods of the Quaternary. Together with these results, levels of genetic diversity in Antarctic and sub-Antarctic populations of Nacella are lower than those found in temperate patellogastropod groups (Bird et al. 2011; Nakano and Ozawa 2005) but comparable to those detected in higher latitudes ones (De Aranzamendi et al. 2009, 2011; Goldstien, Schiel, and Gemmel 2006; González-Wevar et al. 2011). These results further corroborate the impact of Quaternary glacial processes over the patterns of genetic diversity along the whole Antarctic and sub-Antarctic realms. Low levels of genetic diversity as the ones detected in the Antarctic limpet have been also recorded in populations of several Antarctic marine invertebrates including Chorismus antarcticus
(Raupach et al. 2010), Parbolasia corrugatus (Thornhill et al. 2008) and Sterechinus neumayeri (Díaz et al. 2011). Nevertheless, genetic comparisons of standard genetic diversity indices showed lower levels of variability in the lineages from maritime Antarctica ( $N$. concinna) compared to those from South America (N. magellanica) and Kerguelen Island (N. edgari). Such a result suggests a more pronounced demographic effect of Quaternary glacial cycles over the Antarctic species than the sub-Antarctic ones, and that such impact may be directly related to the latitudinal distribution of taxa. Such hypothesis must be further tested through the study of other genus with similar geographic distribution. Patterns of mismatch distribution in species of Nacella are consistent with the patterns of genetic diversity and recognised differences among the analysed taxa and evidence the recent population expansion process that experienced Antarctic and sub-Antarctic species.

\section{Acknowledgements}

We thank the editor and an anonymous reviewer for helpful comments.

\section{Disclosure statement}

No potential conflict of interest was reported by the authors.

\section{Funding}

This study was supported by a Fondecyt Initiation Project 11140087, Chilean Antarctic Institute INACH (Office Project G_04-11) to C.G-W. Projects P05-002 ICM and PFB 023 (Instituto de Ecología y Biodiversidad IEB, Universidad de Chile), to E.P and CG-W. Field access at Kerguelen Island are supported by IPEV programme 1044 Proteker to E.P., J.-P.F. and T.S. We recognise the SCAR AntEco and EBA programmes, and CAML, for encouraging and supporting Antarctic and sub-Antarctic evolutionary biology. This paper also contributes to the SCAR 'State of the Antarctic Ecosystem' (AntEco) programme

\section{References}

Aljanabi, S. M., and I. Martinez. 1997. "Universal and Rapid Salt-Extraction of High Quality Genomic DNA for PCRBased Techniques.” Nucleic Acids Research 25: 4692-4693.

Allcock, A. L., and J. M. Strugnell. 2012. "Southern Ocean Diversity: New Paradigms from Molecular Ecology" Trends in Ecology \& Evolution 27: 520-528.

Aronson, R. B., S. Thatje, A. Clarke, L. S. Peck, D. B. Blake, C. D. Wilga, and B. A. Seibel. 2007. "Climate Change and Invasibility of the Antarctic Benthos." The Annual Review of Ecology, Evolution, and Systematics 38: 129-154.

Barker, P. F., and E. Thomas. 2004. "Origin, Signature and Palaeoclimatic Influence of the Antarctic Circumpolar Current." Earth-Science Reviews 66: 143-162. 
Barker, P. F., G. M. Filippelli, F. Florindo, E. E. Martin, and H. D. Scher. 2007. "Onset and Role of the Antarctic Circumpolar Current." Deep Sea Research Part II: Topical Studies in Oceanography 54: 2388-2398.

Barnes, D. K. A., and L. S. Peck. 2008. "Vulnerability of Antarctic Shelf Biodiversity to Predicted Regional Warming." Climate Research 37: 149-163.

Barnes, D., D. Hodgson, P. Convey, C. Allen, and A. Clarke. 2006. "Incursion and Excursion of Antarctic Biota: Past, Present and Future." Global Ecology and Biogeography 15: 121-142.

Barnes, D. K. A., H. Griffiths, and S. Kaiser. 2009. "Geographic Range Shift Response to Climate Change by Antarctic Benthos: Where to Look." Marine Ecology Progress Series 393: $13-26$.

Bird, C. E., B. S. Holland, B. W. Bowen, and R. J. Toonen. 2007. "Contrasting Phylogeography in Three Endemic Hawaiian Limpets (Cellana Spp.) with Similar Life Histories." Molecular Ecology 16: 3173-3186.

Bird, C. E., B. S. Holland, B. W. Bowen, and R. J. Toonen. 2011. "Diversification of Sympatric Broadcast-Spawning Limpets (Cellana Spp.) within the Hawaiian Archipelago." Molecular Ecology 20: 2128-2141.

Bromham, L., and D. Penny. 2003. “The Modern Molecular Clock." Nature Reviews Genetics 4: 216-224.

Clarke, A., and J. Crame. 1989. "The Origin of the Southern Ocean Marine Fauna." Geological Society of London, Special Publications 47: 253-268.

Clarke, A., and J. Crame. 2010. "Evolutionary Dynamics at High Latitudes: Speciation and Extinction in Polar Marine Faunas." Philosophical Transactions of the Royal Society B: Biological Sciences 365: 3655-3666.

Clarke, A., D. Barnes, and D. Hodgson. 2005. "How Isolated is Antarctica?" Trends in Ecology \& Evolution 20: 1-3.

Convey, P., M. Stevens, D. Hodgson, J. Smellie, C.-D. Hillenbrand, D. K. A. Barnes, A. Clarke, P. J. A. Pugh, K. Linse, and S. C. Cary. 2009. "Exploring Biological Constraints on the Glacial History of Antarctica." Quaternary Science Reviews 28: 3035-3048.

Crame, J. 1999. "An Evolutionary Perspective on Marine Faunal Connection between Southernmost South America and Antarctica." Scientia Marina 63: 1-14.

Cumming, R. A., R. Nikula, H. Spencer, and J. Waters. 2014. "Transoceanic Genetic Similarities of Kelp-Associated Sea Slug Populations: Long-Distance Dispersal via Rafting?” Journal of Biogeography 41: 2357-2370.

Dalziel, I. W. D., L. A. Lawver, J. A. Pearce, P. F. Barker, A. R. Hastie, D. N. Barfod, H.-W. Schenke, and M. B. Davis. 2013. "A Potential Barrier to Deep Antarctic Circumpolar Flow until the Late Miocene?" Geology 41: 947-950.

Dambach, J., S. Thatje, D. Rödder, and Z. Basher. 2012. "Effects of Late-Cenozoic Glaciation on Habitat Availability in Antarctic Benthic Shrimp (Crustacea: Decapoda: Caridea)." PLoS ONE 7: e46283.

De Aranzamendi, M., C. Gardenal, J. Martin, and R. Bastidas. 2009. "Limpets of the Genus Nacella (Patellogastropoda) from the Southwestern Atlantic: Species Identification Based on Molecular Data." Journal of Molluscan Studies 75: 241-251.

de Aranzamendi, M., R. R. Bastidas, and C. Gardenal. 2011. "Different Evolutionary Histories in Two Sympatric Limpets of the Genus Nacella (Patellogastropoda) in the SouthWestern Atlantic Coast." Marine Biology 158: 2405-2418.

Díaz, A., J.-P. Féral, B. David, T. Saucède, and E. Poulin. 2011. "Evolutionary Pathways among Shallow and Deep-Sea Echinoids of the Genus Sterechinus in the Southern Ocean." Deep Sea Research Part II: Topical Studies in Oceanography 58: 205-211.

Dömel, J. S., P. Convey, and F. Leese. 2015. “Genetic Data Support Independent Glacial Refugia and Open Ocean Barriers to Dispersal for the Southern Ocean Sea Spider Austropallene Cornigera (Möbius, 1912)." Journal of Crustacean Biology 35: 480-490.

Downey, R., H. Griffiths, K. Linse, and D. Janussen. 2012. "Diversity and Distribution Patterns in High Southern Latitude Sponges." PLoS ONE 7: e41672.

Edgar, R. 2004. "MUSCLE: A Multiple Sequence Alignment Method with Reduced Time and Space Complexity." BMC Bioinformatics 5: 113.

Excoffier, L., G. Laval, and S. Schneider. 2005. "Arlequin (Version 3.0): an Integrated Software Package for Population Genetics Data Analysis." Evolutionary Bioinformatics Online 1: $37-50$.

Felsenstein, J. 1981. "Evolutionary Trees from DNA Sequences: A Maximum Likelihood Approach.” Journal of Molecular Evolution 17: 368-376.

Filatov, D. A. 2009. "Processing and Population Genetic Analysis of Multigenic Datasets with ProSeq3 Software." Bioinformatics 25: 3189-3190.

Flower, B., and J. Kennett. 1994. "The Middle Miocene Climatic Transition: East Antarctic Ice Sheet Development, Deep Ocean Circulation and Global Carbon Cycling." Palaeography, Palaeclimatology, Palaeoecology 108: 537-555.

Folmer, O., M. Black, W. Hoeh, R. Lutz, and R. Vrijenhoek. 1994. "DNA Primers for Amplification of Mitochondrial Cytochrome C Oxidase Subunit I from Diverse Metazoan Invertebrates." Molecular Marine Biology and Biotechnology 3: 294-299.

Fraser, C., R. Nikula, H. Spencer, and J. Waters. 2009. "Kelp Genes Reveal Effects of Subantarctic Sea during the Last Glacial Maximum." Proceedings of the National Academy of Science, USA 106: 3249-3253.

Fraser, C., M. Thiel, H. Spencer, and J. Waters. 2010. "Contemporary Habitat Discontinuity and Historic Glacial Ice Drive Genetic Divergence in Chilean Kelp." BMC Evolutionary Biology 10: 203.

Fraser, C., R. Nikula, and J. Waters. 2011. "Oceanic Rafting by a Coastal Community." Proceedings of the Royal Society B: Biological Sciences 278: 649-655.

Gérard, K., N. Bierne, P. Borsa, A. Chenuil, and J.-P. Féral. 2008. "Pleistocene Separation of Mitochondrial Lineages of Mytilus Spp. Mussels from Northern and Southern Hemispheres and Strong Genetic Differentiation among Southern Populations." Molecular Phylogenetics and Evolution 49: 84-91.

Gersonde, R., X. Crosta, A. Abelmann, and L. Armand. 2005. "Sea-Surface Temperature and Sea Ice Distribution of the Southern Ocean at the EPILOG Last Glacial Maximum A Circum-Antarctic View Based on Siliceous Microfossil Records.” Quaternary Science Reviews 24: 869-896.

Goldstien, S., D. Schiel, and N. Gemmel. 2006. "Comparative Phylogeography of Coastal Limpets across a Marine 
Disjunction in New Zealand." Molecular Ecology 15: 32593268.

González-Wevar, C. A., T. Nakano, J. Cañete, and E. Poulin. 2010. "Molecular Phylogeny and Historical Biogeography of Nacella (Patellogastropoda: Nacellidae) in the Southern Ocean." Molecular Phylogenetics and Evolution 56: 115-124.

González-Wevar, C. A., T. Nakano, J. Cañete, and E. Poulin. 2011. "Concerted Genetic, Morphological and Ecological Diversification in Nacella Limpets in the Magellanic Province." Molecular Ecology 20: 1936-1951.

González-Wevar, C. A., A. Díaz, K. Gérard, J. Cañete, and E. Poulin. 2012a. "Divergence Time Estimations and Contrasting Patterns of Genetic Diversity between Antarctic and Southern South America Benthic Invertebrates." Revista Chilena De Historia Natural 85: 445-456.

González-Wevar, C. A., M. Hüne, J. Cañete, A. Mansilla, T. Nakano, and E. Poulin. 2012b. “Towards a Model of Postglacial Biogeography in Shallow Marine Species along the Patagonian Province: Lessons from the Limpet Nacella Magellanica (Gmelin, 1791)." BMC Evolutionary Biology 12: 139.

González-Wevar, C. A., T. Saucède, S. A. Morley, S. L. Chown, and E. Poulin. 2013. "Extinction and Recolonization of Maritime Antarctica in the Limpet Nacella Concinna (Strebel, 1908) during the Last Glacial Cycle: Toward a Model of Quaternary Biogeography in Shallow Antarctic Invertebrates." Molecular Ecology 22: 5221-5236.

González-Wevar, C. A., S. L. Chown, S. A. Morley, N. Coria, T. Saucède, and E. Poulin. 2016. "Out of Antarctica: Quaternary Colonization of Sub-Antarctic Marion Island by the Limpet Genus Nacella (Patellogastropoda: Nacellidae)." Polar Biology. 39: 77-89.

Griffiths, H., D. K. A. Barnes, and K. Linse. 2009. “Towards a Generalized Biogeography of the Southern Ocean Benthos." Journal of Biogeography 36: 162-177.

Hewitt, G. 2000. "The Genetic Legacy of the Quaternary Ice Ages." Nature 405: 907-913.

Hunter, R. L., and K. M. Halanych. 2008. "Evaluating Connectivity in the Brooding Brittle Star Astrotoma agassizii across the Drake Passage in the Southern Ocean." Journal of Heredity 99: 137-148.

Janosik, A. M., A. R. Mahon, and K. M. Halanych. 2011. "Evolutionary History of Southern Ocean Odontaster Sea Star Species (Odontasteridae; Asteroidea)." Polar Biology 34: 575-586.

Kemp, A. E. S., I. Grigorov, R. B. Pearce, and A. C. Naveira Garabato. 2010. "Migration of the Antarctic Polar Front through the mid-Pleistocene Transition: Evidence and Climatic Implications." Quaternary Science Reviews 29: 1993-2009.

Lawver, L. A., and L. M. Gahagan. 2003. "Evolution of Cenozoic Seaways in the Circum-Antarctic Region." Palaeogeography, Palaeoclimatology, Palaeoecology 198: 1-27.

Librado, P., and J. Rozas. 2009. "DnaSP V5: A Software for Comprehensive Analysis of DNA Polymorphism Data." Bioinformatics 25: 1451-1452.

Linse, K., H. Griffiths, D. K. A. Barnes, and A. Clarke. 2006. "Biodiversity and Biogeography of Antarctic and SubAntarctic Mollusca." Deep Sea Research Part II: Topical Studies in Oceanography 53: 985-1008.

Livermore, R., A. Nankivell, G. Eagles, and P. Morris. 2005. "Paleogene Opening of Drake Passage." Earth and Planetary Science Letters 236: 459-470.
Mackensen, A. 1999. "Changing Southern Ocean Palaeocirculation and Effects on Global Climate." Antarctic Science 16: 369-386.

Maggs, C. A., R. Castihlo, D. Foltz, C. Henzler, M. T. Jolly, J. Kelly, J. Olsen, K. E. Perez, W. Stam, R. Väinölä, F. Viard, and J. Wares. 2008. "Evaluating Signatures of Glacial Refugia for North Atlantic Benthic Marine Taxa." Ecology 89: S108S122.

Marko, P. B., J. M. Hoffman, S. A. Emme, T. M. Mcgovern, C. C. Keever, and L. N. Cox. 2010. 'The "Expansion-Contraction" Model of Pleistocene Biogeography: Rocky Shores Suffer a Sea Change?' Molecular Ecology 19: 146-169.

Nakano, T., and T. Ozawa. 2005. "Systematic Revision of Patelloida Pygmaea (Dunker, 1860) (Gastropoda: Lottiidae), with a Description of a New Species." Journal of Molluscan Studies 71: 357-370.

Near, T. J., A. Dornburg, K. L. Kuhn, J. T. Eastman, J. N. Pennington, T. Patarnello, L. Zane, D. A. Fernández, and C. D. Jones. 2012. "Ancient Climate Change, Antifreeze, and the Evolutionary Diversification of Antarctic Fishes." Proceedings of the National Academy of Sciences, USA 109: 3434-3439.

Nikula, R., C. I. Fraser, H. G. Spencer, and J. M. Waters. 2010. "Circumpolar Dispersal by Rafting in Two Subantarctic Kelp-Dwelling Crustaceans." Marine Ecology Progress Series 405: 221-230.

Page, T., and K. Linse. 2002. "More Evidence of Speciation and Dispersal across Antarctic Polar Front through Molecular Systematics of Southern Ocean Limatula (Bivalvia: Limidae)." Polar Biology 25: 818-826.

Pearse, J. S., R. R. Mooi, S. J. Lockhart, and A. Brandt. 2009. "Brooding and Species Diversity in the Southern Ocean: Selection for Brooders of Speciation within Brooding Clades?" In Smithsonian at the Poles: Contribution to International Polar Year Science, edited by Krupnik, I., M. Lang, and S. Miller, 181-196. Washington D.C.: Smithsonian Institution Scholarly Press

Pfuhl, H. A., and I. N. McCave. 2005. "Evidence for Late Oligocene Establishment of the Antarctic Circumpolar Current." Earth and Planetary Science Letters 235: 715-728.

Pierrat, B., T. Saucède, A. A. Brayard, and B. David. 2013. "Comparative Biogeography of Echinoids, Bivalves and Gastropods from the Southern Ocean." Journal of Biogeography 40: 1374-1385.

Pons, O., and R. Petit. 1996. "Measuring and Testing Genetic Differentiation with Ordered versus Unordered Alleles." Genetics 144: 1237-1245.

Posada, D., and K. A. Crandall. 2001. "Intraspecific Gene Genealogies: Trees Grafting into Networks." Trends in Ecology \& Evolution 16: 37-45.

Poulin, E., C. Gonzalez-Wevar, A. Díaz, K. Gérard, and M. Hüne. 2014. "Divergence between Antarctic and South American Marine Invertebrates: What Molecular Biology Tells Us about Scotia Arc Geodynamics and the Intensification of the Antarctic Circumpolar Current." Global and Planetary Change 123: 392-399.

Powell, A. 1973. The Patellid Limpets of the World (Patellidae), 1-132. New Zealand: Auckland Institute and Museum Auckland.

Provan, J., and K. Bennett. 2008. "Phylogeographic Insights into Cryptic Glacial Refugia." Trends in Ecology \& Evolution 23: 564-571. 
Raupach, M. J., S. Thatje, J. Dambach, P. Rehm, B. Misof, and F. Leese. 2010. "Genetic Homogeneity and Circum-Antarctic Distribution of Two Benthic Shrimp Species of the Southern Ocean, Chorismus Antarcticus and Nematocarcinus Lanceopes." Marine Biology 157: 1783-1797.

Rintoul, S., C. Hughes, and D. Olbers. 2001. "The Antarctic Circumpolar Current System" (Chapter 4.6). In Ocean Circulation and Climate, edited by Siedler, G., J. Church, and J. Gould, 1-32. Oxford: Academic Press.

Roe, A. D., and F. A. H. Sperling. 2007. "Patterns of Evolution of Mitochondrial Cytochrome C Oxidase I and II DNA and Implications for DNA Barcoding." Molecular Phylogenetics and Evolution 44: 325-345.

Rogers, A. R., and H. Harpending. 1992. "Population Growth Makes Waves." Molecular Biology and Evolution 9: 552-569.

Scher, H. D., and E. E. Martin. 2006. "Timing and Climatic Consequences of the Opening of Drake Passage." Science 312: 428-430.

Scher, H. D., J. M. Whittaker, S. E. Williams, J. C. Latimer, W. E. C. Kordesch, and M. L. Delaney. 2015. "Onset of Antarctic Circumpolar Current 30 Million Years Ago as Tasmanian Gateway Aligned with Westerlies." Nature 523: 580-583.

Shaw, P. W., A. I. Arkhipkin, AND H. Al-Khairulla. 2004. "Genetic Structuring of Patagonian Toothfish Populations in the Southwest Atlantic Ocean: The Effect of the Antarctic Polar Front and Deep-Water Troughs as Barriers to Genetic Exchange." Molecular Ecology 13: 3293-3303.

Shevenell, A., J. Kennett, and D. Lea. 2004. "Middle Miocene Southern Ocean Cooling and Antarctic Cryosphere Expansion." Science 305: 1766-1770.

Slatkin, M., and R. R. Hudson. 1991. "Pairwise Comparisons of Mitochondrial DNA Sequences in Stable and Exponentially Growing Populations." Genetics 129: 555-562.

Stankovic, A., K. Spalik, E. Kamler, P. Borsuk, and P. Weglenski. 2002. "Recent Origin of Sub-Antarctic Notothenioids." Polar Biology 25: 203-205.

Strugnell, J. M., A. D. Rogers, P. A. Prodöhl, M. A. Collins, and A. L. Allcock. 2008. "The Thermohaline Expressway:
The Southern Ocean as a Centre of Origin for Deep-Sea Octopuses." Cladistics 24: 853-860.

Tamura, K., G. Stecher, D. Peterson, A. Filipski, and S. Kumar. 2013. "MEGA6: Molecular Evolutionary Genetics Analysis Version 6.0." Molecular Biology and Evolution 30: 2725-2729.

Thatje, S., C.-D. Hillenbrand, and R. Larter. 2005. "On the Origin of Antarctic Marine Benthic Community Structure." Trends in Ecology \& Evolution 20: 534-540.

Thornhill, D. J., A. R. Mahon, J. L. Norenburg, and K. M. Halanych. 2008. "Open-Ocean Barriers to Dispersal: A Test Case with the Antarctic Polar Front and the Ribbon Worm Parborlasia Corrugatus (Nemertea: Lineidae)." Molecular Ecology 17: 5104-5117.

Valdovinos, C., and M. Rüth. 2005. "Nacellidae Limpets of Southern South America: Taxonomy and Distribution." Revista Chilena De Historia Natural 78: 497-517.

Verducci, M., L. M. Foresi, G. H. Scott, M. Sprovieri, F. Lirer, and N. Pelosi. 2009. "The Middle Miocene Climatic Transition in the Southern Ocean: Evidence of Paleoclimatic and Hydrographic Changes at Kerguelen Plateau from Planktonic Foraminifers and Stable Isotopes." Palaeogeography, Palaeoclimatology, Palaeoecology 280: 371386.

Waters, J. M. 2008. "Driven by the West Wind Drift? A Synthesis of Southern Temperate Marine Biogeography, with New Directions for Dispersalism." Journal of Biogeography 35: 417-427.

Wilson, N. G., M. Schrödl, and K. M. Halanych. 2009. “Ocean Barriers and Glaciation: Evidence for Explosive Radiation of Mitochondrial Lineages in the Antarctic Sea Slug Doris Kerguelenensis (Mollusca, Nudibranchia)." Molecular Ecology 18: 965-984.

Xia, X., and Z. Xie. 2001. "DAMBE: Software Package for Data Analysis in Molecular Biology and Evolution." The Journal of Heredity 92: 371-373.

Zachos, J., M. Pagani, L. Sloan, E. Thomas, and K. Billups. 2001. "Trends, Rhythms, and Aberrations in Global Climate 65 Ma to Present." Science 292: 686-693. 